\title{
JOLANTA SZTACHELSKA
}

Instytut Filologii Polskiej

Uniwersytet w Białymstoku

jsztachelska@wp.eu

\section{PAMIĘTNIKARSTWO. Z DZIEJÓW TERMINU I GATUNKU W XIX W.}

Pamiętnikarstwo jako szczególny rodzaj aktywności pisarskiej, dedykowanej potrzebie zapisania swojego czasu, uprawiane prawdopodobnie od początków piśmiennictwa, według Georga Mischa ${ }^{1}-\mathrm{z}$ pewnością od starożytności, co potwierdzają znane i cytowane w całym cywilizowanym świecie dzieła Ksenofonta (Hellenika, V-IV w. p.n.e.) i Juliusza Cezara (Commentarii de bello Gallico oraz Commentarii de bello civili, 100-44 r. p.n.e.), i dawniej, i dziś przysparza sporo problemów definicyjnych. Dotyczą one zarówno samego terminu „pamiętnik” (a więc i „pamiętnikarstwo”), jak też jego zakresu znaczeniowego, tym bardziej że granice pomiędzy pamiętnikiem i dziennikiem czy opisem podróży są płynne. Owa trudność nie zmniejsza wszakże atrakcyjności samego przedmiotu - dziedzina pamiętnikarstwa wydaje się całością skomplikowaną, ale wielobarwną i niezmiennie pociągającą dla badacza.

Przez pamiętnikarstwo na ogół rozumie się typ prozy dokumentarnej, który sytuuje się pomiędzy nauką (historia i historiografia), publicystyką i literaturą, i który ze względu na niefikcjonalność (lub fikcjonalność szczątkową) oraz funkcjonowanie $\mathrm{w}$ obrębie piśmiennictwa użytkowego (źródło do badań historii), tradycyjnie umieszcza się poza granicami literatury. Najczęściej ma on charakter epickiej narracji o faktach (zdarzeniach) ukazywany z perspektywy życia jednostki. Choć pamiętniki w Polsce uprawia się od XVI w., a XVII w. wyjątkowo w ten typ piśmiennictwa obfitował, aż do początków XIX w. nie stały się one przedmiotem rozważań teoretycznych, nie mieściły się bowiem $w$ zakresie teorii poezji i wymowy. $Z$ drugiej strony aż do XIX w. brakło nazwy określającej tego typu pisarstwo.

1 G. Misch, A History of Autobiography in Antiquity, Cambridge, Mass., 1951. 


\section{Z historii terminu ${ }^{2}$}

Jeszcze w XVIII w. słowo „pamiętnik" miało kilka znaczeń.

Pierwotnie wyraz ten oznaczał człowieka pamiętającego, świadka zdarzeń, nie kojarzono go z piśmiennictwem. Mianem pamiętnika określano także konkretny materialny przedmiot pamiętający jakieś wydarzenie, np. zamek pamiętający feudalne czasy, kościół zbudowany dla upamiętnienia zdarzenia lub poświęcony komuś godnemu pamięci. Natomiast utwór mający upamiętnić coś lub kogoś nazywano w staropolszczyźnie pamiątką. W takim znaczeniu wyraz ten pojawił się w tytule wierszowanej relacji Antoniego Czaki Pamiętnik roku tysiącz [!] siedemsetnego ośmdziesiątego siódmego na Ukrainie, świętującego wizytę Carycy Katarzyny II w Kaniowie i przyjazd Józefa II (1788), gdy w innym XVIII-wiecznym druku mamy konsekwentnie pamiątkę: Pamiątka albo katalog szczęśliwej śmierci niektórych zakonników Societatis Jesu częścia męczeńską Korona częścia żywota świątobliwościa znacznych (Lwów, b.r.).

Dzieła o charakterze historycznym, które dziś jesteśmy skłonni nazywać pamiętnikami, autorzy określali zazwyczaj inaczej, np. dzieje, konotatka wypadków, diariusz czy dukt życia itd. Etykieta „pamiętniki” pojawia się dopiero w późniejszych, najczęściej XIX-wiecznych wydaniach. Na przykład ks. Wojciech Dembołęcki nazwał swoje dzieło Przewagi Elearów polskich, co ich niegdyś lisowczykami zwano, a tytuł Pamiętniki o lisowczykach zawdzięcza wydawcy z 1859 roku, który uznał za stosowne gatunkowo dookreślić utwór. Podobnie było z ks. Augustynem Kordeckim i jego Nowq Gigantomachia, która ukazawszy się w Krakowie w 1657 r. w wersji łacińskiej, w przekładzie polskim Józefa Łepkowskiego (Warszawa 1858) uzyskała podtytuł Pamiętnik oblężenia Częstochowy roku $1655 . .$. , by w kolejnych wydaniach figurować jako Pamiętnik oblężenia..., ale już bez nazwy nadanej mu przez autora.

Pamiętniki staropolskie miewały tytuły najrozmaitsze, świadczące o dużej pomysłowości ich autorów ${ }^{3}$, tylko nie - Pamiętniki. Pewną zmianę do-

2 Znaczenia terminu rekonstruuję na podstawie następujących źródeł: Słownik literatury polskiej XIX wieku, red. J. Bachórz, A. Kowalczykowa, Wrocław 1991; Słownik literatury staropolskiej, red. T. Michałowska, Wrocław 1990; M. Klimowicz, Literatura Oświecenia, Warszawa 1989; Słownik literatury polskiego Oświecenia, red. T. Kostkiewiczowa, Wrocław 1977.

3 Jak choćby Krzysztofa Pieniążka Ethica, albo Zwierciadło żywota... ku przykładowi braciej okazana, utwór napisany w 1607, wyd. 2 przez Kazimierza W. Wójcickiego w „Bibliotece starożytnej pisarzy polskich", t. 1, Warszawa 1843. 
strzec można dopiero w XVIII w. Co prawda i wtedy jeszcze większość dzieł pamiętnikarskich ukrywa się pod metaforycznymi nazwami o proweniencji wręcz barokowej, np.: Echo na świat podane czyli procedura podróży y życia mego awantur na cześć y chwałę P. Bogu w Świętey Trójcy Jedynemu y Najświętszey Matce Chrystusa Pana mego y Wszystkim Świętym przeze mnie samej wydana ta książka Salomei Reginy de Pilsztynowey Medycyny Doktorki y Okulistki w Roku 1760 w Stambule , bądź zapożyczonymi z historiografii - Franciszek Karpiński nazwał swoją autobiografię Historia mego życia i ludzi, z którymi żyłem $(1844)^{5}$, ale jednocześnie pojawiają się pierwsze sygnały zwiastujące pewne zmiany. Pojęcie pamiętnika w znaczeniu współczesnym utrwala się stopniowo jako bardziej sposobne do nazwania różnych świadectw przeszłości pod wpływem literatury europejskiej, zwłaszcza francuskiej i angielskiej, w których różnego typu Mémoires ogłaszano od XV i XVI w. Udział tego typu wypowiedzi zwiększa się sukcesywnie w piśmiennictwie aż do XIX w., gdzie osiągnie apogeum, będąc wyrazem coraz silniejszej potrzeby wyrażania $\mathrm{w}$ piśmiennictwie - zarówno dokumentarnym, jak i fikcjonalnym ludzkiej podmiotowości.

Nazwa „pamiętnik” zanim zacznie oznaczać typ dokumentu osobistego, pojawia się $\mathrm{w}$ piśmiennictwie polskim także w znaczeniu „księgi, w której zapisane jest to, co warte zapamiętania", przede wszystkim zatem w tytułach najdawniejszych czasopism i wydawnictw zbiorowych. Autor hasła „Pamiętniki” w Encyklopedii powszechnej Orgelbranda, Franciszek H. Lewestam, notuje wiele takich przykładów, ogłaszanych, jak pisze: „już to przez pojedyncze osoby, już to przez łączną pracę układane" ${ }^{\prime \prime}$. Wymienia zatem m.in.: „Pamiętnik polityczny i historyczny przypadków, ustaw, osób, miejsc i pism wiek nasz szczególnie interesujących" (Warszawa 1782-1792) ks. Piotra Świtkowskiego; „Nowy pamiętnik warszawski, czyli dziennik historyczno-polityczny, tudzież nauk i umiejętności" (od 1801-1805) Franciszka Dmochowskiego; „Pamiętnik warszawski” (1809) Ludwika Osińskiego; „Pamiętnik lwowski” (Lwów 1816); „Pamiętnik umiejętności moralnych i literatury” (Warszawa 1829); „Pamiętnik naukowy” (Kraków 1837) etc. Ostatnim przykładem tego rodzaju może być „Pamiętnik Towarzystwa Literackiego im. Adama Mickiewicza" wychodzący od 1887 r. we Lwowie, w 1902 r. prze-

\footnotetext{
4 Znana od 1896 r. w streszczeniu, wyd. I kompletne, Kraków 1957.

5 Pierwsze wydanie u I. Moraczewskiego (Poznań 1844) pełne było błędów; wydanie kompletne (i poprawione) w opracowaniu R. Sobola ukazało się dopiero w Warszawie w $1987 \mathrm{r}$.

6 Pamiętniki, [w:] Encyklopedia powszechna Orgelbranda, Warszawa 1865, t. 20, s. 303-304.
} 
kształcony w istniejący do dzisiejszego dnia "Pamiętnik Literacki”, najważniejsze i najstarsze pismo środowiska polonistycznego.

Wśród przykładów ilustrujących posługiwanie się nazwą "pamiętnik" w wydaniach prac zbiorowych Lewestam podaje przykłady z różnych krajów, przeważnie jednak w wersji francuskojęzycznej, co wskazuje jednoznacznie na proweniencję tego zwyczaju, np. „Histoire et Mémoires de l'Académie des sciences (de Paris) depuis son établissement en 1660 jusque, en 1790" (Paryż 1701-1793; 164 tomy); „Histoire et Mémoires de l'Académie des inscriptions et belles letters de 1701-93” (Paryż 1717-1809; 50 tomów); "Mémoires de l'Académie de sciences et belles letters de Berlin" (Berlin 1770-1804); „Mémoires de l'Academie Imperiale des sciences de St. Petersbourg" (Petersburg 1822), ale również „Memoirs of literary and philos. society of Manchester" (Londyn 1789-1796) etc. W tym samym artykule autor z przekonaniem informuje o rosnącej w XVIII w. modzie na czytanie i wydawanie pamiętników w wydaniach zbiorczych, która dość szybko przyjmie się także w Polsce, apogeum osiągając $\mathrm{w}$ XIX $\mathrm{w}$.

Dodać też należy, iż w drugiej połowie XVIII w. upowszechnia się nazwa „pamiętnik" (mémoire) jako nazwa gatunkowa, obsługująca m.in. powieści czyli pamiętniki fikcyjne, np. Claude Alexandrine Guerin de Tencin, Hrabia de Comminge, albo Pamiętniki jego życia (Warszawa 1786) lub Kalwinka na pustyni wychowana albo Pamiętnik Miledy B. (Supraśl 1788), co wskazuje jednoznacznie, że nazwa po pierwsze uległa leksykalizacji, po drugie przeniesienie jej z dzieł naukowych czy czasopism na beletrystykę podwyższało $\mathrm{w}$ intencji autora rangę jego utworu.

Moda na wszelkiego rodzaju mémoire na Zachodzie Europy towarzyszyła w XVIII w. przemianom w metodologii nauk historycznych, rosło znaczenie świadectwa przeszłości, prowadzące do istotnych przekształceń w dziedzinie pojmowania dziejowości i roli podmiotu. Można powiedzieć, iż rosnąca potrzeba stworzenia polskiego odpowiednika tej nazwy wpłynęła na zmianę znaczenia staropolskiego wyrazu „pamiętnik". Stopniowo przekształca się on w określenie różnego rodzaju materiałów historycznych gromadzonych przez współczesnego obserwatora lub uczestnika pamiętnych wydarzeń. W tym znaczeniu był to termin niesłychanie popularny, wręcz modny przez cały XIX w. - a i dziś jest w nim używany, choć na pierwszy plan wysunęła się zdecydowanie inna warstwa znaczeniowa, w XVIII w. jeszcze nieobecna. Chodzi o pamiętnik rozumiany jako wspomnienia osobiste, rodzaj autobiografii. Jest rzeczą charakterystyczną, że nie posłużył się tym określeniem żaden XVIII-wieczny autor pamiętników typu autobiograficznego. Ludziom tej epoki nazwa "pamiętnik”, wchodząca dopiero w użycie jako synonim relacji 
opartej na osobistym doświadczeniu, ale wyraźnie przedmiotowej, kojarzyła się łatwiej z historiografią niż z autobiografią.

Trudno jednoznacznie wskazać, od kiedy termin „pamiętnik” we właściwym (czyli współczesnym znaczeniu) funkcjonuje w języku krytyki literackiej XIX w. W latach 20. tego stulecia nie ma go jeszcze w popularnym podręczniku Euzebiusza Słowackiego ${ }^{7}$, który wśród "rodzajów wymowy w mowie niewiązanej” wymienia co prawda - „opowiadanie dziejów ludzi czyli historię" oraz biografię, ale nie pamiętnik. Lecz już w Prawidłach wymowy i poezji w dziale "historia” autor nie definiując wprawdzie terminu, wyraźnie używa go do opisu dzieł Juliusza Cezara, podkreślając: „opisywał historię własnych wypraw, którym przez skromność imię pamiętników (commentarii) nadał" 8 .

Z kolei, w znanym dziele Stanisława Kostki Potockiego O wymowie i stylu z 1815 r. w rozdziale XXIII O historii i pamiętnikach za czasów dzisiejszych po wywodzie na temat rozwoju historiografii zachodnioeuropejskiej, zwłaszcza francuskiej i włoskiej, następuje dłuższy passus omawiający funkcję pamiętników. Potocki, porównując je z historią, wyraźnie wskazuje na ich inność, niższość: „Pamiętniki wskazują rodzaj składni, w której pisarz ma za cel uwiadomić o tym wszystkim co się zdarzyło w periodzie jaki obejmują, ale jedynie czyny, których miał osobistą znajomość, albo które się go tyczą, lub tłumaczą postępki jakiejś osoby albo dokonanie jakiegoś czynu, co jest przedmiotem pamiętników jego. Stosownie do tego nie można wyciągać od takowego pisarza poszukiwań tak głębokich i znajomości tak rozległych jak od historyka. Nie jego poczynaniom ton powagi i godności, od którego się oddalać historykowi nie godzi. Ma wolność mówienia o sobie samym i opowiadania zdarzeń potocznych i zabawnych. Naczelnym przymiotem tego rodzaju składni jest, by była żywa i pociągająca i by uwiadamiała o rzeczach małych i wielkich. Przystoi on mianowicie tym, co lubią pisać o sobie i co mają za ważne te wszystkie zdarzenia, których uczestnikami byli" ${ }^{\prime}$.

Ciekawe, ale XIX-wieczni wydawcy odczuwali potrzebę uzasadnienia tak bujnego rozrostu pamiętnikarstwa.

Michał Grabowski, wydawca Pamiętników domowych (Warszawa 1845; tytuł to inwencja wydawcy), mieszczących dwa mniejszego znaczenia utwory, Wacława Borejki i Karola Micewskiego, zaopatrzył swą edycję przedmową, w której wyłuszcza cel publikacji jako „tworzenie poezji krajowej”. Litera-

7 E. Słowacki, Dzieła z pozostawionych rękopisów ogłoszone, t. I-II, Wilno 1826, określenia z t. II.

8 Tenże, Prawidła wymowy i poezji, Wilno 1847 (wyd. 4), s. 175.

9 S.K. Potocki, O wymowie i stylu, cz. 2, t. 4, 1815, s. 119. 
tura dążąca do prawdy potrzebuje źródeł bytu - wyjaśnia krytyk. „Wynika stąd dla literatury, dla poezji, dla sztuki w ogólności potrzeba materiałów, których one dotąd mało się domagały; materiałów domowej, najpoufalszej historii ludów", ich gromadzenie ,jest jednym z najcharakterystyczniejszych znamion obecnej chwili", stąd wynika "powszechny popęd ku ich zbieraniu i ogłaszaniu" 10 .

W latach 50. XIX stulecia nazwa "pamiętnik" wydaje się przechodzić do powszechnego użycia, widać to zwłaszcza w czasopismach nastawionych na przedruk różnego typu dokumentów historycznych, regestrów, pamiętników, listów etc., jak „Biblioteka Warszawska” (1841-1914, najwięcej tego typu materiałów w latach 40. i 50. za redakcji K.W. Wójcickiego), „Kronika Rodzinna” (1867-1914), lwowski „Dziennik Literacki” (ukazuje się w latach 1852-1854, 1856-1865). W t. 4 „Biblioteki Warszawskiej” z 1853 r., w kronice literackiej anonimowy autor informuje: „pisanie pamiętników weszło teraz w modę we Francji; każdy prawie, czy kto umie, czy nie umie władać piórem, wtajemnicza publiczność do ważnych i nieważnych wypadków życia swego, wyjawia tajniki serca, skrytości duszy; każdy przed konfesjonałem opinii publicznej chce się spowiadać [...]. Dowodem, że się o tym nie śniło filozofom, są słowa, którymi Jan Jakub chełpliwie swoją spowiedź zapowiedział: Czynię, czego nikt przede mną i nikt po mnie nie uczyni. [...] Dumas pierwszy wprowadził na ulicę tę pamiętniko-manię. Już czterdzieści tomów wspomnień swoich opowiedział publicznie, a sądząc po drobiazgowym wyliczeniu faktów, nie ukończy opowiadać przed śmiercią. Jego pamiętnik to komedyjka, której teatrem jest cała Francja, począwszy od Ludwika Filipa po gałganiarza paryskiego. Słowem jest to nowa encyklopedia powszechna, pisana z nieporównanym dowcipem [...]"11.

Termin wchodzi do edukacyjnej praktyki, notuje go np. popularny, wielokrotnie przedrukowywany podręcznik Jana Rymarkiewicza, Nauka prozy czyli stylistyka (Poznań 1855) czy Franciszka Salezego Dmochowskiego, Nauka prozy, poezji i zarys piśmiennictwa polskiego... (Warszawa 1864). W obu tych podręcznikach prócz definicji pamiętnika: u Rymarkiewicza: „Pamiętniki są to opowiadania wydarzeń, jakich piszący sam doświadczył w ciągu życia swojego, w połączeniu z wypadkami, których był świadkiem, oraz z opisaniem osób, z którymi żył, i miejsc, w których się znajdował"12; u Dmochowskiego: „Wiele osób, które znamienite miejsce zajmowały w społeczeństwie

\footnotetext{
10 Pamiętniki domowe, wyd. M. Grabowski, Warszawa 1845, s. 6.

11 [b.a.], Kronika literacka, „Biblioteka Warszawska” 1853, t. IV, s. 530.

12 J. Rymarkiewicz, Nauka prozy czyli stylistyka, Poznań 1855, s. 238.
} 
i albo też były świadkami ważnych wypadków, zostawiło po sobie pamiętniki. Dzieła takie są zajmujące i ciekawe, a przy tym dostarczają ważnych materiałów do historii. Jednakże trzeba je czytać z rozwagą i krytyką, gdyż prawie każdy człowiek chciałby wystawić swoje czyny w najlepszym świetle, a potępić przeciwników" ${ }^{\prime 1}$, pojawia się też próba hierarchizacji wydawanych w XIX w. pamiętników, w przeważającej liczbie dotyczących XVII i XVIII w., można by rzec nawet, iż autorzy tych podręczników kreują rodzaj staropolskiego kanonu pamiętnikarstwa polskiego.

Nadal najbardziej znaczące wydają się pamiętniki osób, które zaznaczyły się w życiu politycznym. Rymarkiewicz wymienia np.: Aleksandra Jełowickiego, Moje wspomnienia (t. 2, Paryż 1839); Jędrzeja Kitowicza, Pamiętniki obejmujace panowanie Augusta III i Stanisława Augusta (Poznań 1845); Juliana Niemcewicza, Pamiętniki czasów moich. Dzieło pośmiertne... (Paryż 1848, wyd. nowe Lipsk 1868); Jana Chryzostoma Paska, Pamiętniki (dwa wyd.: Wilno 1843 i 1854); ks. Wojciecha Dembołęckiego, Przewagi Elearów polskich, co ich niegdyśs Lissowczykami zwano (Poznań 1623 i Puławy 1830); Franciszka Karpińskiego, Pamiętniki (Poznań 1844). Dmochowski posługuje się niemal tymi samymi przykładami, dorzucając do tego zestawu pisane już w XIX w. wspomnienia Kajetana Koźmiana (we fragmentach ukazywały się w czasopismach; całość: Warszawa 1907) i F. Salezego Dmochowskiego (częściowo publik. Warszawa 1858).

Obaj autorzy mają także świadomość, iż czym innym jest użyteczność pamiętnika jako źródła historycznego, czym innym zaś ich wartość literacka, oba te przymioty, jak utrzymują, pojawiają się w jednym dziele niezmiernie rzadko. W tym też sensie podkreślają znaczenie dzieła Jana Chryzostoma Paska.

\section{Wiek edytorstwa}

Podkreślić warto rolę indywidualnych inicjatyw, prowadzących do wydawania pamiętników. Jako inicjatorzy, mecenasi i redaktorzy poszczególnych tomów a nawet całych, wielotomowych serii wsławili się m.in.: Julian Ursyn Niemcewicz, wydawca Zbioru pamiętników historycznych o dawnej Polszcze (6 tomów wydanych w latach 1822, 1830, 1833 w Warszawie, Puławach i we Lwowie), wśród których znalazły się pierwsze edycje Diariuszów Sa-

13 F.S. Dmochowski, Nauka prozy, poezji i zarys piśmiennictwa polskiego w 3 częściach, Warszawa 1864 , s. 41. 
muela i Bogusława Maskiewiczów oraz słynna Transakcja Stefana Żółkiewskiego; Karol Sienkiewicz, wydawca Skarbca historii Polski (2 tomy, Paryż 1839-1840), pierwszy edytor Pamiętników ks. Jędrzeja Kitowicza; następnie Kazimierz Władysław Wójcicki, projektodawca Biblioteki starożytnej pisarzy polskich (2 wyd. 6-tomowe, Warszawa 1843-1844), opublikował tu m.in. żywot Krzysztofa Pieniążka. W Poznaniu działał Jan Konstanty Żupański, wydawca i redaktor polskich pamiętników z XVIII w. (Poznań 1861-1875), w tym: pamiętników Jana Kilińskiego (jedna $\mathrm{z}$ kilku wersji), gen. Józefa Zajączka, gen. Henryka Dąbrowskiego, Józefa Sułkowskiego, Michała Ogińskiego, gen. Lwa Engelhardta, pamiętnik Wawrzyńca Engeströma. Inni znani wydawcy to Edward hr. Raczyński, Lucjan Siemieński, Tytus Działyński, Zawadzcy w Wilnie, w mniejszym zakresie Aleksander Kraushar, Adam Pawiński, Walery Przyborowski. Odnotować też warto, iż od 1897 r. wychodzi w Warszawie „Biblioteka dzieł wyborowych”, w której drukują się pamiętniki dawne i nowe, dotyczące w coraz większym stopniu XIX w. Tu m.in. ukazały się wspomnienia: Anny Potockiej, Fryderyka Skarbka, Franciszka Karpińskiego (wydanie nowe), Józefa Wysockiego, Henryka Biegeleisena, ks. Augustyna Kordeckiego (kolejne wydanie Nowej Gigantomachii), W. Marrené-Morzkowskiej Cyganeria warszawska, M. Berga i J.J. Sieviersa.

W dziedzinie edytorstwa pamiętników dawnych szczególna wydaje się pozycja Józefa Ignacego Kraszewskiego, który był bodaj najlepiej przygotowanym i świadomym wydawcą. Często recenzował różne wydawnictwa historyczne, miał także własną koncepcję pamiętnikarstwa.

Pamiętnik był dlań pograniczną formą piśmiennictwa, należącą bądź do historii jako nauki, bądź też do literatury. Widział w nim dokument, gdy przekazywał wierny, obiektywny zapis zdarzeń historycznych, ale dopuszczał także inną możliwość - pamiętnik jako relację autentystyczną, w której zdarzenia historyczne tworzą tło, na którym rozgrywają się życiowe przygody autora. Do pierwszej grupy zaliczał relacje Stanisława Albrychta Radziwiłła, Bogusława Maskiewicza i Jędrzeja Kitowicza, do odmiany drugiej Paska.

W XIX w. w pamiętnikarstwie nastąpiło, zdaniem Kraszewskiego, skrzyżowanie się tych dwu odmian, które zintegrowały się w formie autentystycznej opowieści. Reguły gatunkowe i funkcjonalne utraciły swoją ważność także w odmianie dokumentarnej. Te tendencje zaznaczą swoją obecność w drugiej połowie wieku. Z pewną niechęcią konstatował: „Co to jest pochlebstwo smakowi wieku. Lubią pamiętniki, więc wszystko ich barwę, formę lub, tylko nie wiedzieć po co i dlaczego, nazwę przybiera. - Tym sposobem teraz, czym są właściwie pamiętniki i czym być miały, nikt się nie nauczy, gdy w jed- 
nych biografie, $w$ drugich rozprawy, $w$ trzecich dawne akta i korespondencje, w czwartych diariusze się znajdują. Ale jesteśmy w wieku, w którym sobie wyraźnie wszyscy ze wszystkich prawideł i klasyfikacji żartują, dajmy więc pokój, i niech będzie wiekowi naszemu, jak pożąda"14.

Pamiętniki, listy i innego rodzaju materiały historyczne wydawał już w czasach działalności w "Atheneum” wileńskim (1841-1851). W czasie pobytu w Dreźnie zainicjował Bibliotekę pamiętników i podróży po dawnej Polsce, w której w latach 1870-1871 ukazało się 6 tomów różnych materiałów z XVIII i XIX w. Wśród nich znalazły się m.in.: podróż po Polsce Fryderyka Szulca (z 1793), Pamiętniki Hansa Schweinichena do dziejów Śląska i Polski 1552-92, Pamiętniki Stanisława Augusta Poniatowskiego w przekładzie B. Zaleskiego, Pamiętniki Seweryna Bukara oraz kilka pamiętników z lat 1792-1812. Za największe jego edytorskie dokonania uchodziło $\mathrm{w}$ epoce wydanie pamiętników Jana Poczobuta Odlanickiego z lat 1640-1684 (1877), w którym J.I. Kraszewski dokonał profesjonalnego opisu rękopisu, zaopatrzył w przypisy i przedmowę oraz opracowanie Pamiętnika anegdotycznego z czasów Stanisława Augusta Ludwika Cieszkowskiego, wydanego przez J.K. Żupańskiego (Poznań 1867).

\section{Fenomen pamiętnikarstwa w XIX w.}

Pojawienie się w przestrzeni kultury XIX w. zabytków polskiego pamiętnikarstwa od renesansu do oświecenia było - jak ocenić można z perspektywy czasu - szczególnym fenomenem polskiego życia czasów niewoli. Jak notuje Bibliografia pamiętników polskich i Polski dotyczacych Edwarda Maliszewskiego ${ }^{15}$, wydrukowano wówczas około 3500 tekstów, przy czym rejestr Maliszewskiego uwzględniał nie tylko pamiętniki drukowane, ale także rękopisy i utwory publikowane w czasopismach. Przyczyny tego pamiętnikarskiego boomu wytłumaczyć można nie tylko oddziaływaniem kontekstu zachodnioeuropejskiego, a więc potrzebą naśladownictwa, ale ogólnie zwiększeniem się możliwości technicznych w produkcji książek i prasy, jej dostępnością, poszerzeniem się sfery odbiorców, a także sytuacją kultury polskiej doby niewoli: ożywieniem życia polskiego i zwiększeniem rangi pisarstwa naro-

14 Cyt. wg wyd. współczesnego: J.I. Kraszewski, Pamiętniki, oprac. W. Danek, Wrocław 1972, s. 231.

15 Wydana po raz pierwszy w 1928 r., później dopełniona pracą Jerzego Skrzypka Bibliografia pamiętników polskich do 1964 r., Wrocław 1976. 
dowego, braku instytucji kształtujących opinie, podziałem społeczeństwa na kraj i emigrację ${ }^{16}$. Ważnym elementem była wiara $\mathrm{w}$ potęgę słowa drukowanego, wreszcie motywy psychologiczne - szukanie w obrazie przeszłości namiastki utraconego życia narodowego, odwrócenie się od teraźniejszości i nastawienie nostalgiczne. Edycje pamiętników i źródeł stały się przyczyną trwającego niepomiernie dłużej niż na Zachodzie Europy zainteresowania historią i w znaczący sposób przedłużyły funkcjonowanie pisarstwa historycznego w sytuacji, gdy modernizująca się Europa dawno ogłosiła jego anachroniczność.

Masowe wydawanie pamiętników i różnych materiałów historycznych w XIX w. z jednej strony było odpowiedzią na rozbudzone zainteresowanie czytelników, z drugiej skutecznie je podsycało. Masowość nie sprzyjała profesjonalizmowi w dziedzinie edytorstwa. W latach 80. XIX w. poświęcił temu zagadnieniu sporo miejsca Józef Kazimierz Plebański, wszechstronnie wykształcony historyk o orientacji pozytywistycznej. W jego tekście omawiającym edytorską praktykę J.I. Kraszewskiego ${ }^{17}$, znajdujemy wiele uwag na ten temat, a tekst nie utracił aktualności.

Plebański z troską ocenia stan współczesnego XIX-wiecznego edytorstwa, widząc przyczynę jego złej kondycji w zbyt krótkim okresie prowadzenia systematycznych badań naukowych na polu dziejopisarstwa, krótkotrwałej działalności Towarzystwa Przyjaciół Nauk i słabości uniwersytetów (Wileńskiego i Jagiellońskiego). Brak takiego publicznego miejsca, z którego by „nasza literatura historyczna mogła czerpać światło jasnego poglądu, ścisłość naukowego badania, wszechstronną krytykę źródeł, tudzież zachętę i niezbędne wskazówki dla młodzieży, pragnącej się poświęcić uprawie tej gałęzi wiedzy", to według niego poważne utrudnienie. Sam zapał i gotowość bowiem nie wystarczą. Pisał: „Trudy i nakłady, łożone na tym polu przez Raczyńskich, Ossolińskich, Czackich, Działyńskich, Przeździeckich, Lubomirskich i wielu innych, pozostaną na zawsze chwalebnym świadectwem zamiłowania nauki i gorliwości o wzrost oświaty publicznej; ale braku szkoły zastąpić nie mogły. Prace w tym kierunku przedsiębrane, gromadziły z gorączkową prawie niespokojnością wszelki materiał historyczny, jaki się nastręczał w różnej wartości dziennikach, pamiętnikach, listach prywatnych, doku-

16 Zob. opinię A. Cieńskiego w: tenże, Pamiętnikarstwo polskie w wieku XVIII, Wrocław 1981, s. 70 i n. Zob. także: tenże, Z dziejów pamiętników w Polsce, Opole 2002.

17 J.K. Plebański, Wydawnictwo pamiętników. O pamiętnikach historycznych wydanych przez J. I. Kraszewskiego, [w:] Książka Jubileuszowa dla uczczenia pięćdziesięcioletniej działalności literackiej J. I. Kraszewskiego, Warszawa 1880. 
mentach urzędowych, swojskich i zagranicznych, w relacjach osób publicznych, bez należytej ścisłości i metody naukowej i krytycznej. Na tej drodze zwiększono ogrom faktów historycznych; ale zwracając uwagę przeważnie na ich ocenę literacką, nie oceniono ich wartości źródłowej, nie zbadano ich autentyczności, słowem: nie wykazano ich wartości historycznej. Tłumaczenia dawnych drukowanych autorów ogłaszano za nowoodkryte źródła, dla przeróżnych względów familijnych i fakcyjnych, obcinano lub przeinaczano relacje i pamiętniki współczesnych świadków" ${ }^{\prime \prime}$.

Edytorzy, jak pisze Plebański, nie tylko nie mieli odpowiedniego wykształcenia historycznego, ale też dopuszczali się manipulacji $\mathrm{w}$ imię interesów rodzinnych i politycznych. Brak metodyki w postępowaniu historycznym to najpoważniejszy zarzut: „są nasze prace historyczne skarbnicą starożytnych pamiątek, otoczonych chwalebną synowską czcią i miłością, która wznosi się niekiedy aż do idealizowania i ubóstwiania osób i czynów historycznych, mających dla naszego życia narodowego zupełnie przeciwstawne znaczenie" ${ }^{19}$. W ostatnich latach nastąpił jednak duży postęp $\mathrm{w}$ tej dziedzinie, rozwinęła się krytyka źródeł, edytorzy wykazują się większą ostrożnością i starannością.

Pamiętnik jest według Plebańskiego formą świadectwa o przeszłości niezwykle atrakcyjną. Czytelnika pociąga w nim bliskość przeszłości, ale także „wyrazistsze piętno prawdy, stwierdzonej doświadczeniem i przykładem codziennego życia. W przykładach zaś jest wielka siła [...]" 20 .

Prawda pamiętnika to indywidualne, subiektywne spojrzenie na dzieje: „Pamiętnik nie poddaje się powadze żadnej szkoły historiozoficznej, nie krępuje się wyłącznie ani dedukcją ani indukcją [...]. Historia w pamiętniku nie jest wstępem jakiejś wielkiej epopei; ale zazwyczaj udatną, wdzięczną nader gawędą" ${ }^{21}$. Ta wolność może być jednak zwodnicza, gdyż opierając się na "gruncie subiektywnym, służą po większej części celom i widokom osobistym" 22, z tym większym krytycyzmem należy je traktować. Plebański podkreśla: „Różnica pomiędzy dziełem historycznym a pamiętnikiem na tym głównie polega, że autor pamiętnika ma więcej na uwadze swoje czyny, aniżeli wypadki swojego czasu, więcej to, co się tyczy jego osoby, aniżeli to, co się dzieje wokół niego; pisze to, czego się dotykał, co widział

\footnotetext{
18 Tamże, s. 465.

19 Tamże, s. 466.

20 Tamże, s. 475.

21 Tamże.

22 Tamże.
} 
lub co słyszał, pod pierwszym wrażeniem bez dochodzenia prawdy z pomocą innych źródeł; historyk zaś zbiera przede wszystkim niezachwiane świadectwa prawdy z autentycznych źródeł, porównywa je ze sobą, waży na szali sprawiedliwego sądu, bada wszystkie wypadki współczesne, wnika w ich ducha i stara się za pomocą intuicji odkryć idee, które przenikały minione wieki" ${ }^{23}$. Pamiętnikarze nader często bezwiednie zapisują swoje niezbyt chwalebne czyny, nie ma jednak powodu, by nad tym faktem się rozwodzić, naukowe podejście do tego typu świadectw wymaga postawy neutralnej, bezstronnej, nie zaś tego, co obserwować można w dyskusjach prasowych. Jakie są zatem zadania badacza pamiętników? Historyk odpowiada z powagą:

„Historyczna wartość «Pamiętników» jako źródeł, zależy od tych samych warunków, na których opiera się wartość każdego innego świadectwa historycznego. Badacz dziejów zwracać tu winien pilną uwagę na stopień nauki i wykształcenia autora pamiętnika; dalej na moralną stronę jego charakteru, na stanowisko, jakie zajmował w społeczeństwie, i na czynny udział, jaki mógł mieć w wypadkach epoki, której obraz nam kreśli. Im wyższe zajmuje autor pamiętnika stanowisko w hierarchii politycznej, z którego wszystkie wypadki dokładnie mógł poznać, im światlejszym szczyci się umysłem, pojmującym dokładnie zdarzenia swej epoki, im niewątpliwszą jest moralna strona jego charakteru [...], tym cenniejszym staje się pamiętnik dla badacza dziejów, bo tylko taki świadek będzie wiernym tłumaczem dążeń swej epoki" 24 .

Ważne jest także dostrzeżenie wartości literackiej pamiętników. Plebański pisze: każdy pamiętnik może być źródłem do badań historycznych, od tego jest naukowa krytyka źródeł, ale nie każdy posiada wartość artystyczną: „Nie można [...] sprawiedliwie ocenić wartości literackiej żadnego pamiętnika, jeżeli go nie porównamy z resztą współczesnej mu literatury, jeżeli nie zwrócimy pilnej uwagi na stosunek, jaki pod względem naukowym i artystycznym zachodzi między stopniem oświaty danej epoki a pisarzem pamiętnika danej chwili" 25 .

O wartości pamiętnika decyduje też sposób jego wydania. Krytyk pisze: „sposób wydania pamiętników z oryginalnych rękopismów lub wiarygodnych kopii decyduje stanowczo o historycznej wartości przechowywanego pomnika". Rękopisy często znajdują się w opłakanym stanie, są uszkodzone,

\footnotetext{
Tamże, s. 476.

24 Tamże.

25 Tamże, s. 477.
} 
fragmentaryczne. Osobną kwestią jest drastyczność niektórych spraw utrwalonych w pamiętnikowych zapisach. Czasem trzeba nieco wygładzić język, ale $\mathrm{z}$ zachowaniem wielkiej ostrożności. $\mathrm{W}$ ogóle edytor winien opracować tekst do druku, a także ujawnić naniesione zmiany czy poprawki. Nie ma tu miejsca na dowolność. „Dla tej przyczyny nie ma wiele pamiętników, wydanych przez Raczyńskiego, żadnej historycznej wartości" 26.

Co do Kraszewskiego, jako wydawca często znajdował się „,w konieczności wygładzania rękopismów względem stylu i języka; lecz wychodzące spod jego ręki wydawnictwa nie budzą żadnych obaw co do nadwerężania samych faktów. W odpowiedzi, jaką na zapytanie nasze co do sposobu korzystania z rękopismów od szanownego Jubilata odebraliśmy, pisze Kraszewski ze względu na rękopism pamiętników Ochockiego, nabyty od rodziny: «Był on pisany stylem takim i tak cynicznie miejscami, że musiałem go dopiero uczynić prèsentable, ręczę jednak za to, że nic ani dodałem ani zmieniłem, i sumienność w przepisaniu zachowałem jak największą. Nigdzie i nigdy nie robiłem swoich dodatków»" 27.

\section{Najciekawsze pamiętniki dawne}

Z ciekawszych pamiętników dawnych zasłużoną sławą cieszył się utwór Jana Chryzostoma Paska Pamiętniki Jana Chryzostoma Paska z czasów panowania Jana Kazimierza, Michała Korbuta i Jana II 1656-168828, dostępny czytelnikom najpierw we fragmentach, drukowanych już w latach 20. XIX stulecia, potem staraniem hrabiego Edwarda Raczyńskiego wydany po raz pierwszy w Poznaniu w 1836 r., wielokrotnie w ciągu XIX stulecia przedrukowywany, w opracowaniu Z. Węclewskiego (1877), potem B. Gubrynowicza (Lwów 1898). Wydanie krytyczne, zupełne w opracowaniu Jana Czubka ukazało się we Lwowie w 1923 r. (Biblioteka Pisarzów Polskich PAU). Pamięt-

26 Tamże, s. 478.

27 Tamże. Kraszewski oczywiście nie był nieomylny, zwłaszcza w kwestiach językowych. Bardzo krytyczną ocenę jego działalności redaktorskiej w odniesieniu do pamiętnika Jana Władysława Odlanickiego, polegającej na uwspółcześnieniu języka przekazu (Kraszewski nie docenił historycznego znaczenia polszczyzny kresowej z XVII w.) oraz zastosowaniu swoistej cenzury (usunął rusycyzmy i białorutenizmy) prezentuje: B. Smolińska, O działalności wydawniczej Kraszewskiego (na przykładzie druku "Pamiętnika" Jana Władysława Poczobuta Odlanickiego z roku 1877), „Przegląd Humanistyczny” 1977, nr 7-8.

28 Tytuł został nadany przez wydawcę, bo rękopis pozbawiony był strony tytułowej i zakończenia. 
nik doczekał się sporej literatury krytycznej, pisali o nim m.in. J.I. Kraszewski i K.W. Wójcicki.

Bronisław Chlebowski ${ }^{29}$ próbował dociec fenomenu Paskowego pisarstwa. Pisał z przekonaniem: „Nie będę tu wyliczał całego szeregu ogłoszonych drukiem diariuszów, co zresztą stanowiłoby małą tylko cząstkę zaginionych lub ukrywających się jeszcze zabytków tego rodzaju. Pomniki te, o ile są ważne dla dziejów politycznych i historii obyczajów, o tyle po większej części w dziejach literatury nie mają dla siebie miejsca. Luźność i bezplanowość opracowania, tak $\mathrm{w}$ treści, jak $\mathrm{w}$ formie, nie pozwala wprowadzać ich $\mathrm{w}$ zakres literatury, inaczej bowiem zniesiemy wszelką granicę między produkcją artystyczną a prostym wyrażeniem myśli za pomocą pisma. W takim razie każdy przywilej klasztorny, akt notarialny lub wyrok sądowy, każda skarga lub pozew stałyby się pomnikami literatury. Pomiędzy Pamiętnikami Paska a całą gromadą diariuszów zachodzi taka różnica, jak między obrazem bitwy malowanym przez zdolnego malarza a planem takowej, narysowanym naprędce przez naocznego świadka" 30 .

Chlebowski zadawał sobie pytanie, jak to się stało, że człowiek bez wykształcenia mógł osiągnąć „tak barwną formę opowiadania”. Sekret tkwił według niego $\mathrm{w}$ dawnym polskim życiu publicznym, w jego mówionym charakterze. To oralność stała się źródłem twórczości staropolskiej. Pasek, gorliwy uczestnik sejmików i żołnierz, tę zdolność, czyli niewątpliwy talent oratorski, łatwość, dosadność i malowniczość opowiadania, wyrobił sobie przez powtarzanie. Stosunkowo łatwo to sprawdzić, twierdzi komentator: „ilekroć [...] wychodzi z roli opowiadacza, a usiłuje być pisarzem, wtedy znika cała prostota, życie i prawda z jego opowieści, a pojawia się panegiryczna nadętość i styl makaroniczny"31. Znaczenie pamiętników Paska polega na ich autentyczności, na tym, że: „odbijają one życie narodowe (szlacheckie naturalnie) w całej pełni i barwności, odtwarzają je bowiem bezpośrednio, nie załamując jego promieni w pryzmacie jakichś wzorów i tendencji literackich i naukowych" 32 .

Słusznym uznaniem cieszyły się też pamiętniki ks. Jędrzeja Kitowicza. Był on autorem dwóch, szeroko komentowanych w XIX-wiecznej krytyce

29 B. Chlebowski, Jan Chryzostom Pasek i jego „Pamiętniki”, „Tygodnik Ilustrowany” 1879, ser. 3 , t. 7, nr 164 .

30 Tamże, według przedruku artykułu w: B. Chlebowski, Od Kochanowskiego do Brzozowskiego, Warszawa 1979, s. 345.

31 Tamże, s. 387.

32 Tamże, s. 388. 
utworów: Opisania zwyczajów i obyczajów polskich za Augusta III ${ }^{33}$ oraz Pamiętników, czyli Historii polskiej ${ }^{34}$. Podwaliny sławy literackiej Kitowicza założył Karol Sienkiewicz, domagając się w 1839 r., by zaliczyć uczonego księdza do „lepszych pisarzów z wieku Stanisława Augusta”. Dzisiaj nie ma wątpliwości, że Kitowicz na to zasługuje, zalety jego pisarstwa to przede wszystkim cechy stylu i języka, programowo dowcipnego, żywego, ale także krytycyzm w ujmowaniu faktów ${ }^{35}$. Jak wynika z autorskiej przedmowy do Pamiętników, przedrukowanej w artykule K.W. Wójcickiego w 1853 r. ${ }^{36}$, Kitowicz uważał się za historyka, a w jego epoce znaczyło to mniej więcej tyle, co filozof. „Pierwsza przyczyna do notowania zdarzeń za życia mego była - pisał - naturalne przywiązanie do dziejów albo historii, którą [...] mam za mistrzynię umysłu i oświecicielkę najdroższą" ${ }^{37}$. Druga to doświadczenie lektury innych dziejopisarzów, którzy prawdę mieszają z fałszem. Kitowicz podkreślał potrzebę krytycyzmu i naoczności, potępiał fantazjowanie prowadzące do zafałszowania obrazu. Pisał o swoim celu: „potomności myśliłem dać moje pamiętniki, aby prawda zagmatwana piórami postronnych pisarzów lub pochlebców nie zginęła" 38 .

To, co jest zaletą Kitowicza, z trudem odnajdziemy w pamiętniku Marcina Matuszewicza ${ }^{39}$. Autora znano powszechnie w Rzeczypospolitej pod koniec panowania Augusta III i w pierwszych latach Stanisława Augusta, gdyż nader często zabiegał o względy szlachty i magnaterii. Był nie tylko politykiem, ale i człowiekiem pióra, poetą, przekładał m.in. Horacego. Miał opinię znakomitego mówcy, pomieścił go w słynnym zbiorze Swada polska

33 We fragmentach publikowany w latach 20. XIX w. w „Pamiętniku Warszawskim”, w całości po raz pierwszy w Skarbcu historii polskiej, t. 1, Paryż 1839; wyd. krytyczne w opracowaniu W. Zawadzkiego, Lwów 1883, późniejsze w Bibliotece Narodowej, w oprac. M. Janika, Kraków 1925.

34 Fragmenty ukazały się w Skarbcu..., Paryż 1839, w całości przez E. Raczyńskiego, Poznań 1840 i wielokrotnie przedrukowywany; następnie w oprac. W. Zawadzkiego, Lwów 1882, także w Przemyślu 1882 w oprac. A. Kaczerby.

35 Zob. P. Matuszewska, Wstęp do: J. Kitowicz, Pamiętniki, czyli Historia polska, oprac., wstęp P. Matuszewska, komentarz Z. Lewinówna, wyd. 2 poprawione, PIW 2005; H. Barycz, Jędrzej Kitowicz - pamiętnikarz, powieściopisarz, historyk?, „Przegląd Humanistyczny” 1963, nr 2.

36 K.W. Wójcicki, Jędrzej Kitowicz..., „Biblioteka Warszawska” 1853, t. 1.

37 Tamże, Przedmowa, s. 51.

38 Tamże.

39 M. Matuszewicz, Diariusz życia mego, opublikowany przez A. Pawińskiego pt. Pamiętniki... kasztelana brzeskiego-litewskiego, 1714-1765, Warszawa 1876, 4 tomy; wyd. współczesne w oprac. B. Królikowskiego, komentarze Z. Zielińska, Warszawa 1986 (Biblioteka Pamiętników Polskich i Obcych, red. Z. Lewinówna). 
i łacińska Daneykowicz (1745), publikowali później jezuici wileńscy w „Wiadomościach Literackich". Jemu współcześni nie orientowali się, że pisze pamiętnik. W tytule zamieścił zresztą: diariusz - „dla wiadomości potomkom moim spisany”, w zakończeniu zaś: "to prywatne pisanie, dla domowej tylko wiadomości". Mimo nazwania go diariuszem, czyli pamiętnikiem osobistym, utwór Matuszewicza jest jednym z najbardziej szczegółowych w naszej memuarystyce opisów panowania Augusta III. Pisał go nie tylko polegając na pamięci własnej, ale także korzystając z notatek, relacji innych świadków, relacji pisemnych, włączał ponadto gotowe teksty własne sprzed lat i cudze - listy, manifesty, mowy etc. W biogramie Matuszewicza, zamieszczonym w Encyklopedii powszechnej Orgelbranda Julian Bartoszewicz wysoko podnosił wartość historyczną i obyczajową jego pisarstwa. Adam Pawiński, wydawca pamiętnika, podkreślał prawdziwość ${ }^{0}$ i świadomość artystyczną autora. Pisał: "Cechuje je przede wszystkim forma artystyczna. Autor nadał całemu dziełu charakter opowieści. Nie ma tu luźnych notat, spostrzeżeń metereologicznych, kronikarskim sposobem zapisanych. Obraz życia rozwija się w całej pełni, urozmaicony opowiadaniem ważniejszych zdarzeń zaszłych na szerszej widowni życia publicznego" ${ }^{41}$. Po opublikowaniu Diariusza... zewsząd posypały się recenzje. O pamiętnikach pisali m.in. A. Tyszyński ${ }^{42}$, H. Schmitt ${ }^{43}$. Do historii przeszła jednak recenzja Włodzimierza Spasowicza opublikowana w 1876 r. w "Ateneum" (t. 4), potem przedrukowana w Studiach nie z natury (Wilno 1881) pt. M. Matuszewicz jako pamiętnikarz. Przeszła do historii, bo wywołała gwałtowny sprzeciw Henryka Sienkiewicza. W artykule Spasowicza Matuszewicz wystąpił $\mathrm{w}$ jednym szeregu $\mathrm{z}$ innymi piewcami szlachetczyzny - Wincentym Polem i Władysławem Syrokomlą. Litwosowi to zestawienie wydało się wielce niestosowne, zobaczył w nim wszechstronną manipulację, groźną, bo dokonywał jej czołowy reprezentant opcji prorosyjskiej w polskiej krytyce, do tego profesjonalista. Przyszły autor Trylogii, zawsze krytyczny wobec Syrokomli, któremu miał za złe i dyletantyzm w historiozofii i w artyzmie, ujmował się przede wszystkim za Polem, w którym widział „bezwzględnego narodowca” i „Katona polskości”. Zestawia-

\footnotetext{
40 A. Pawiński, O życiu i pismach Marcina Matuszewicza, wstęp do: M. Matuszewicz, Pamiętniki... kasztelana..., „Prawdą istotnie rządzi się Matuszewicz, o ile w stanie byliśmy sprawdzić jego opowieść. Ze skwapliwości, z jaką autor gromadzi dokumenta, wnosić należy, że starał się być dokładny, a więc ku prawdzie dążył", s. XXIII.

41 Tamże, s. XXIV.

42 A. Tyszyński, „Biblioteka Warszawska” 1877, t. 2.

43 H. Schmitt, „Ruch Literacki” 1877, s. 45-52.
} 
nie go w jednym rzędzie z Matuszewiczem, który bezkrytycznie zapisywał w swoim pamiętniku wszystko, co czyni z przeszłości Polski, jak się wyraża Sienkiewicz - „morze ciemności”, w którym "trudno się dopatrzyć jakiegoś światełka”, wydała się pisarzowi grubym nadużyciem. Replikował Spasowiczowi słynną, po wielokroć potem powtarzaną frazą, w której zapisał się jego gorący stosunek do przeszłości: „Chrystusować przeszłość jest przesadą, ale nazwać ją jawnogrzesznicą jest nie mniejszą - i choćbyśmy zgodzili się na to, że dzięki mesjanizmowi mieliśmy głowę w obłokach, to drugi kierunek może przez niebaczność wytrącić nam podstawę spod nóg. Musimy stać na tym, co jest nasze - inaczej przyjdzie spaść gdzieś za nisko, bo aż do stosowania się, «w trzecim czy czwartym pokoleniu do nowych zewnętrznych warunków»". Nie wahał się powiedzieć swoim współczesnym: tylko przeszłość nam została. „Pol nauczył nie tylko współczesnych, ale i przyszłe pokolenia kochać przeszłość - i jako taki ma ogromne znaczenie dla krytyki historycznej - ta bowiem, oparta na miłości, może i musi wydać plon zdrowy i pożyteczny. Inaczej doprowadziłaby tylko do wielkiego nihil - i w sensie społecznym usunęłaby podstawę spod nóg narodu" 44 .

Mimo powszechnego zainteresowania pamiętnikiem kasztelana brzeskiego - umieszczają go w swoich już XX-wiecznych historiach literatury S. Tarnowski, A. Brückner i I. Chrzanowski, odczucia krytyki były podobne do tych sienkiewiczowskich. Karol Estreicher tak oto w liście prywatnym rekomendował je Zygmuntowi Kaczkowskiemu: „Do czasów saskich są wielkiej wagi pamiętniki Marcina Matuszewicza [...], który rąbał się, pił, zrywał sejmy, procesował się, przekupywał i dawał przekupywać, dobijał się łaski magnatów - i wszelkie nieuczciwe czyny opowiada dobrodusznie jako rzecz wielkiej wagi i wielkiego patriotyzmu. [...] Widać, że to już taka epoka" 45 . W. Konopczyński pamiętnik Matuszewicza nazwie „mimowiednym zwierciadłem czasów saskich" ${ }^{46}$.

Wydawanie dawnych pamiętników polskich wywarło ogromny wpływ na bieżące życie literackie. Twórczość Kaczkowskiego, Kraszewskiego, Sienkiewicza, Żeromskiego i wielu innych pisarzy, nie tylko zresztą historycznych, wyglądałaby prawdopodobnie zupełnie inaczej, gdyby nie inspiracje,

44 H. Sienkiewicz, Mieszaniny literacko-artystyczne, cz. 2, Dzieła, t. XLVIII, Warszawa 1902, s. $107-108$.

45 Cyt. za: W. Piasecki, Estreicher a warsztat literacki „Olbrachtowych rycerzy”, [w:] Ksiega pamiątkowa ku czci Karola Estreichera, Kraków 1964, s. 266.

46 W. Konopczyński, Od Sobieskiego do Kościuszki, Warszawa 1909, s. II. 
jakimi się stały. Wszechstronny wpływ pamiętnikarstwa prześledzić można u Józefa Ignacego Kraszewskiego. Wiele tu może być przykładów wykorzystania przez pisarza autentycznych materiałów historycznych, w tym pamiętników. Na przykład w opowiadaniu historycznym Starościna bełska, którego bohaterką jest Gertruda z hr. Komorowskich hr. Potocka, uwieczniona w nieśmiertelnej Marii Antoniego Malczewskiego, wykorzystał Kraszewski prócz dokumentów dotyczących obyczajowości, mentalności dawnej szlachty, także korespondencję z epoki oraz pamiętniki Chrząszczewskiego i Cieszkowskiego. Pamiętnik Mroczka (1870) z pewnością nosi w sobie fascynację autora osobą i stylem słynnego Jana Chryzostoma Paska. Konwencje gatunkowe pamiętnikarstwa oraz własne doświadczenie edytora odcisnęły swoje piętno również na innych utworach, wykorzystujących już w tytulaturze podobieństwo do memuarów, np. Jaszka Orfanem zwanego żywota $i$ spraw pamiętnik (1884), Adama Polanowskiego, dworzanina Króla Imci Jana II, notatki (1888), Raptularz pana Mateusza Jasienieckiego (1879); do tego dorzucić trzeba także utwory o problematyce współczesnej, np. Pamiętnik panicza (1875) czy Dziennik Serafiny (1876). Pierwszy z utworów posłużył Kraszewskiemu autokompromitacji narratora-bohatera. Podobny zabieg powtórzy po latach $\mathrm{w}$ zapomnianej grotesce $\mathrm{Z}$ pamiętnika (Warszawa 1903) W.St. Reymont.

Innym przykładem oddziaływania w obrębie literatury pięknej może być twórczość Henryka Sienkiewicza. Powszechnie wiadomo, iż autor Trylogii już w młodości zafascynowany dawną literaturą polską szeroko wykorzystywał autentyczne historyczne źródła. Jak twierdzą badacze jego twórczości, przy konstruowaniu cyklu korzystał m.in. z: Księgi pamiętniczej Jakuba Michałowskiego, Pamiętników Paska, Nowej Gigantomachii ks. Augustyna Kordeckiego, pamiętników: Joachima Jerlicza, Mikołaja Jemiołowskiego, Bogusława Radziwiłła oraz Albrychta Stanisława Radziwiłła, Jakuba Władysława Łosia, Jana Stefana Wydźgi, Jakuba Sobieskiego oraz Samuela i Bogusława Maskiewiczów.

Ciekawie wykorzystał zwłaszcza ostatnie z wymienionych źródeł, czyli Pamiętniki Bogusława Maskiewicza z lat 1643-1649 (wydane przez J.U. Niemcewicza w Zbiorze pamiętników o dawnej Polszcze, t. V, Puławy 1830). Maskiewicz pojawia się w Ogniem i mieczem we własnej osobie. Skrzetuskiemu powracającemu z poselstwa opowiada o wyprawie księcia, a przy okazji dowiadujemy się, że to człowiek uczony, choć młody i pamiętnikarz. Sienkiewiczowski narrator nazywa go „Ksenofontem wyprawy”. Jego oczami Skrzetuski ogląda twierdzę w Kudaku, wpływ pamiętnika zaznacza się też w scenach kreślących bitwę o Machnówkę. 
Inspiracja dotyczyła nie tylko kolorytu epoki, ale także mentalności dawnych Polaków. W słynnym odczycie O powieści historycznej (1889) ${ }^{47}$, będącym polemiką z opinią duńskiego krytyka Georga Brandesa goszczącego z wykładami w Warszawie (1885 i 1886) i twierdzącego, że powieść historyczna to "prawdziwa kawa figowa”, Sienkiewicz oponował, iż dzięki dokumentom mamy możliwość wniknięcia w sposób myślenia i odczuwania naszych przodków, możemy przeszłość fortunnie rekonstruować. Miał również ciekawy pomysł wykorzystania dawnego języka. Nie próbował imitować staropolszczyzny, czerpał natomiast z idiomatyki i składni staropolskiej. „Język dawny - pisał do przyjaciela - polega najwięcej na toku, który ma prawie powagę łaciny, nie zaś na sadzeniu dzikimi archaizmami. [...] Żeby dobrze pisać, potrzeba znać nie tylko Polaków z XVI i XVII wieku, ale i autorów łacińskich, przekłady ich dawniej dokonane, bo na nich kształcili się nasi i duchem ich się przejęli. Potrzeba też umieć odtworzyć sferę pojęć właściwą współczesnym ludziom, co już jest rzeczą intuicji" 48. Umiejętność korzystania z konwencji pamiętnikarskiej obserwować można również w jednej z najgłośniejszych powieści współczesnych Sienkiewicza, Bez dogmatu (1890), napisanej jako journal intime i kreślącej z maestrią duchowość dekadenta.

Literacki wpływ pamiętników staropolskich i oświeceniowych sięga rzecz jasna poza XIX w. Fascynację epoką Potopu znajdziemy zatem u Wiktora Gomulickiego (Car widmo) i Stanisława Wyrzykowskiego, ale także u Kossak-Szczuckiej (powieść Złota wolność).

Pamiętnikarze dawni to przede wszystkim mężczyźni. Nie oznacza to jednak, że nie było wśród nich kobiet. O jednej z pierwszych poinformował czytelników „Biblioteki Warszawskiej” w 1893 r. Aleksander Brückner. Jej wierszowany pamiętnik, datowany na 1685 r., odkrył przypadkiem w Cesarskiej Bibliotece w Sankt Petersburgu ${ }^{49}$. Anna Stanisławska (właściwie Zbąska) w 77 trenach opisuje swoje niełatwe życie. Jej pamiętnik pod efektownym tytułem Transakcyja albo opisanie całego życia jednej sieroty został wydany dopiero $\mathrm{w}$ XX w. ${ }^{50}$ Wiedza o tym, że kobiety realizują się poprzez aktywność

\footnotetext{
47 Wygłosił go Sienkiewicz 4 kwietnia 1889 r. w Krakowie, pierwodruk w: „Słowo” 1889, nr 98-101.

48 W liście do M. Godlewskiego, 1 września 1880, w: H. Sienkiewicz, Listy, t. 1, cz. 2, red. J. Krzyżanowski, oprac. M. Bokszczanin, Warszawa 1977, s. 34.

49 A. Brückner, Wiersze zbieranej drużyny. Pierwsza autorka polska i wierszowana jej autobiografia, „Biblioteka Warszawska" 1893, t. 4.

50 A. Stanisławska, Transakcyja albo opisanie całego życia jednej sieroty, w oprac. I. Kotowej w Bibliotece Pisarzy Polskich Akademii Umiejętności, Kraków 1935; tejże, szkic poświęcony autorce w: „Pamiętnik Literacki” 1934, XXXI. Wyd. nowe w oprac. P. Borka, Kraków 2003.
} 
pisarską, najprawdopodobniej była natchnieniem do wykorzystania konwencji pamiętnikarskiej w oryginalnym romansie Klementyny z Tańskich Hoffmanowej pt. Dziennik Franciszki Krasinskiej w ostatnich latach panowania Augusta III pisany (1825), uchodzącym dziś za jeden z najciekawszych przykładów twórczości powieściowej w okresie przedlistopadowym.

Niezwykłym przykładem pamiętnikarstwa kobiecego jest Proceder podróży i życia mego awantur (tytuł skrócony) Reginy Salomei z Rusieckich Pilsztynowej, napisany w Stambule w $1760 \mathrm{r}$. W wieku 14 lat ta kobieta niemająca większego wykształcenia wychodzi za mąż za luteranina Jakuba Halpira, lekarza i okulistę, z którym wyjeżdża do Stambułu. Lekarka, samouk, tytułuje się dumnie doktorką medycyny i okulistką. Pamiętnik ukazuje nie tylko jej przedziwne medyczne praktyki, w których znajomość medycyny naturalnej sąsiaduje z gusłami i wiarą w czary, ale jest przede wszystkim zapisem jej romansowego życia i niezwykłego jak na kobietę pociągu do podróży od rodzinnej Nowogródczyzny do Stambułu, od Kamieńca do Petersburga, od Kijowa i Żytomierza do Karyntii, Lublany, Wiednia i Wrocławia, Lwowa, Jass i Juszczuku. To, co przydaje niezwykłości temu utworowi, to silna osobowość autorki, przekonanie o ważności jej osoby i „życia awantur", a także wiara, że jej pisanie dotrze do czytelnika. Pierwszą wzmianką o Pilsztynowej i jej pamiętniku był artykuł lekarza L. Glatmana Doktorka medycyny i okulistka polska w XVIII wieku $w$ Stambule ${ }^{51}$, zawierający prócz sylwetki autorki (z wieloma nieścisłościami) również streszczenie jej pamiętnika, wydanego dopiero $\mathrm{w} X X \mathrm{w} \cdot{ }^{52}$

\section{Koniec wieku - pamiętniki artystów}

Już w XIX w. postrzegano ilościową przewagę pamiętnika nad dziennikiem. Był to rys zdecydowanie polski, który objaśnić można z pewnością rustykalnym charakterem polskiej kultury szlacheckiej (pamiętników mieszczańskich jest niewiele, chłopskich nie ma prawie wcale), której pamiętnik (jako księga rodowa) stał się typowym wyrazem, ale także wpływem czynników politycznych, z pewnością zaś ukształtowanym historycznie ideałom służby społecznej, potrzebom poświęcenia dla narodu, świadomym ograni-

51 L. Glatman, Doktorka medycyny i okulistka polska w XVIII wieku w Stambule, „Przewodnik naukowy i literacki" 1896.

52 S. Pilsztynowa, Proceder podróży i życia mego awantur..., z autografu Czartoryskich, red. R. Pollak, oprac. M. Pełczyński, Kraków 1957. 
czeniom potrzeb jednostki. Proporcje te zmienią się w drugiej połowie XIX w., gdy do czytelnika polskiego zacznie docierać memuarystyka zachodnioeuropejska innego rodzaju, przede wszystkim głośne dzienniki wielkich artystów.

W okresie romantyzmu głośne były przede wszystkim beletryzowane pamiętniki Johanna Wolfganga Goethego (Dichtung und Wahrheit, 1811-1814) oraz Podróż włoska (1816), posiadające niezwykłe znaczenie kulturowe jako wzorzec edukacyjnej podróży intelektualno-artystycznej oraz Pamiętniki zza grobu (1848-1850) romantyka francuskiego René Chateaubrianda, wielogatunkowe, rozbijające mit o jednolitości stylu, nade wszystko przenikliwe jako odważna autoanaliza osobowości twórczej. Przestrzeń więzienia ukazywał głośny pamiętnik włoskiego karbonariusza Silvio Pellico (Moje więzienia, 1832), na którym wzorować się będą nie tylko spisujący swe wrażenia z przymusowej izolacji więźniowie, ale również zainteresowani tym tematem twórcy literatury pięknej. W drugiej połowie wieku ukazały się wspomnienia Alfreda de Vigny (Journal d'un poète, 1867), rozpoczynając tym samym typ pamiętników pisarzy, z których najgłośniejszy będzie bodaj Dziennik poufny Henri Frédérica Amiela. Pisany w latach 1841-1881 rękopis liczył sobie 17000 stron i choćby z racji objętości nie mógł liczyć na wydanie. Po śmierci szwajcarskiego pisarza Edmond Scherer przygotował do druku dwutomowy wybór Fragments d'un journal intime (1882-1884), zaopatrując edycję apologetyczną przedmową, w której zaprezentował intymistykę Amiela w kontekście dzieł Rousseau oraz Obermana Senancoura. Dziennik spotkał się z entuzjastyczną recepcją pisarzy i myślicieli całego świata, do których dotarł zresztą w błyskawicznych tłumaczeniach. Wzbudził zachwyt najwybitniejszych przedstawicieli kultury tworzących w XIX i XX w. Ślady lektury Amiela znajdujemy m.in. u Bourgeta, Taine'a, Tołstoja, Sienkiewicza i Brzozowskiego. Zaczerpnięte stamtąd określenie le paysage mental (krajobraz jest odzwierciedleniem duszy) weszło do literackiej frazeologii modernistów. Jeszcze w XX w. o jego pisarstwie pisało się stylem paradoksu; raz, iż jest ono „stężonym destylatem trucizny - niszczycielskiej analizy moralnej zniechęcającej do działań". Innym razem - iż Amiel to moralista na miarę Rousseau, a na najbardziej zadziwiających stronach - „poeta życia kosmicznego" 53 .

Nie mniejszą popularnością cieszyły się też opublikowane w latach 80 . dzienniki Benjamina Constanta i Stendhala. Żaden z nich nie miał już jednak takiego odzewu.

53 Ch. Guyot, w: Literatura francuska, red. A. Adam, G. Lerminier, E. Morot-Sir, t. II, Warszawa 1980, s. 686. 
W 1887 r., jeszcze za życia starszego z braci (Edmunda), a w 17 lat po śmierci młodszego (Juliusza) rozpoczęto druk wielkiego dziennika braci Goncourtów ${ }^{54}$. W ciągu 9 lat wyszło dziewięć tomów tej szczególnej politycznej, literackiej, artystycznej i towarzyskiej kroniki życia Francji. Objęła ona okres II Cesarstwa, wojnę francusko-pruską, oblężenie Paryża, Komunę i III Republikę. Bracia pisali: „Nasza droga literacka jest dosyć dziwna. Do powieści doszliśmy poprzez historię. Nie tak się postępuje. A jednak postępowaliśmy logicznie. Na czym opiera się historia? Na dokumencie. A cóż jest dokumentem powieści, jeśli nie życie?" 55 . Ale była to nie tylko manifestacja dokumentaryzmu. Goncourtowie zaprezentowali styl łączący w sobie najskrajniejszy naturalizm $\mathrm{w}$ połączeniu $\mathrm{z}$ najbardziej wyrafinowaną wrażliwością estetyczną. Tak zaczęła się kariera écriture artiste; odtąd wszystko, co wyszło spod pióra artysty, stawało się równie cenne, jak to, co zostało zamierzone jako literackie arcydzieło.

Najciekawsze pamiętniki polskich pisarzy także wykazywały związki z konwencjami literackimi swoich czasów.

Franciszek Karpiński swój pamiętnik zatytułowany Historia mego wieku $i$ ludzi, z którymi żyłem pisać zaczął na początku XIX w., ostatecznie zamknął zaś swoją opowieść w 1822 r., na cztery lata przed śmiercią. Rękopis znany był kilku przyjaciołom. Ksiądz Korniłowicz, pisząc biografię poety, kopiował jego fragmenty. Biografia ukazała się w 1827 r., a obszerne cytaty dawały wgląd w całość. Pamiętnik wydano w 1844 r. przez I. Moraczewskiego (Poznań 1844), niestety edycja roiła się od błędów, nosiła na sobie liczne ślady cenzury pruskiej. Do tego wydania kilkakrotnie fragmenty ukazywały się $\mathrm{w}$ prasie ówczesnej. Potem wielokrotnie pamiętnik wznawiano, wydanie czwarte z przedmową Piotra Chmielowskiego ukazało się w Warszawie w 1896 r. ${ }^{56}$

To, co wyróżnia pamiętnik Karpińskiego na tle epoki, to rozbudowanie i pogłębienie warstwy autobiograficznej utworu. Główną osią narracji uczynił historię swego życia; tworzą ją z jednej strony różne zdarzenia i sytuacje zewnętrzne, z drugiej - rozbudowana sfera refleksyjno-emocjonalna, zapis rozwoju osobowości. Cechą niezwykłą jest - jak pisze Roman Sobol - „,szczerość granicząca chwilami z bezwiednym cynizmem i niezmierzonym humorem,

\footnotetext{
54 I wydanie pełne: Journal. Mémoires de la vie littéraire, text intégral établi et annoté par R. Ricatte, Monaco 1956.

55 E. i J. de Goncourt, Dziennik. Pamiętniki z życia literackiego, wybór i przekł. J. Guze, Warszawa 1988, s. 116.

56 Wyd. wsp. zob. przyp. 5.
} 
wprowadzanie licznych intymnych, niekiedy nawet drastycznych szczegółów oraz daleko posunięty subiektywizm w ocenie ludzi i spraw. Nie wszystko $\mathrm{w}$ tym pamiętniku jest zgodne $\mathrm{z}$ prawdą obiektywną; wszystko natomiast jest prawdziwe $z$ perspektywy przeżyć, stanów emocjonalnych narratora człowieka czułego" 57 .

Koncepcja pamiętnika, jaką tu zastosowano, wykazuje wpływ Wyznań J.J. Rousseau oraz utworów L. Sterne'a (Życie i myśli Tristrama Shandy, wyd. 1760 oraz Podróż sentymentalna przez Francję i Włochy, wyd. 1768; pierwszy przekład polski 1845). Warstwa historiograficzna nie przedstawia większej wartości, bo to $\mathrm{w}$ istocie autobiografia zespolona $\mathrm{z}$ autoportretem duchowym narratora, gdzie prawda miesza się ze zmyśleniem, a rzeczywistość $\mathrm{z}$ fikcją.

Podobny typ pisarstwa spotykamy w pamiętniku Trzy po trzy Aleksandra Fredry, najznakomitszego polskiego komediopisarza czasów romantyzmu. Fredro do spisywania wspomnień przystąpił około 1844 r., po dwóch latach zakończył redakcję brulionową, ale powracał do pamiętnika jeszcze kilkakrotnie i wprowadzał poprawki aż do lat 70. Planował także jego dalszy ciąg, ostatecznie prac nie ukończył, choć pozostawił po sobie pisane po $1869 \mathrm{r}$. Zapiski starucha - ogród nieplewiony, zbiór rozmaitości, wśród których znalazły się utwory rozmaite gatunkowo: fraszki, epigramaty, przysłowia, aforyzmy, notatki, zapiski.

Wspomnienia Fredry dotyczą przede wszystkim jego przeżyć wojskowych i doświadczeń wojennych w armii napoleońskiej, ale znacznie różnią się od zapisów pamiętnikowych tego typu. Różni je głównie nieszablonowa osobowość autora, który jest żołnierzem, ale i poetą, ponadto konstrukcja całości oraz walory narracyjne. Opowieść Fredry nie respektuje chronologii, jest meandryczna, pełna anegdot i dygresji. Autor stylizuje ją na gawędę, odwołując się tym samym do literatury mówionej zakorzenionej w kulturze szlacheckiej. Udaje, że nie panuje nad historią i plecie trzy po trzy (stąd tytuł utworu), w gruncie rzeczy z maestrią włada słowem i bawi się kompozycją, wciągając w grę czytelnika. Jest to znakomity autoportret autora, wbrew pozorom, także zaprawiony melancholią.

Pamiętnik Fredry był częściowo ogłaszany po czasopismach. Systematycznie publikowała jego fragmenty "Gazeta Polska” w 1877 r. (od nr 64-139, z przerwami), część wydrukował H. Biegeleisen w „Bibliotece Warszawskiej" (1892, t. II) oraz S. Schnür-Pepłowski, Z pamiętników po A. Fredrze,

57 R. Sobol, Wstęp do: F. Karpiński, Historia mego wieku i ludzi, z którymi żyłem, przygot. E. Aleksandrowska, Z. Goliński, Warszawa 1987, s. 19. 
Kraków 1899 i 1900. W całości Trzy po trzy. Pamiętniki z epoki napoleońskiej wydał H. Mościcki, z przedmową A. Grzymały-Siedleckiego w 1917 r. w Krakowie.

\section{Pamiętnikarstwo współczesne}

W drugiej połowie wieku na rynku literackim zaczęło stopniowo pojawiać się piśmiennictwo wspomnieniowe związane z przeżyciem pokoleniowym pozytywistów, czyli powstaniem styczniowym. Jeden z najwcześniejszych zbiorów tego typu, Polska w walce, przygotowany przez Agatona Gillera, wyszedł w Paryżu już w 1868 r. Ten sam autor opublikował również swoje wspomnienia na temat zesłania i pobytu na Syberii $z$ okresu jeszcze przedstyczniowego: Podróż więźnia etapami do Syberii w 1854 r. (1866) oraz $\mathrm{Z}$ wygnania (1870). Stopniowo relacji tych przybywało. Wiele $\mathrm{z}$ nich ukazywało się $\mathrm{w}$ czasopismach galicyjskich, np. Zapiski z powstania 1863-1864 Jakuba Gordona („Mrówka” Lwów 1869), Polska i Moskwa Apolla Nałęcz-Korzeniowskiego („Ojczyzna” 1864). W Krakowie Stanisław Koźmian opublikował w latach 90. pamiętnik pt. Rzecz o roku 1863.

W okresie pozytywizmu pojawiły się relacje pisane przez ludzi żyjących na przełomie XVIII i XIX w., a także opowieści o życiu towarzyskim i literackim lat 40. Wyróżniał się wśród nich pamiętnik ziemianina wielkopolskiego, organicznika i powstańca z 1830 r., Dezyderego Chłapowskiego ${ }^{58}$. Inny charakter miały wspomnienia Antoniego Edwarda Odyńca, publikowane od 1867 r. (Listy z podróży), który idąc wzorem Goethego, tj. beletryzując swoje relacje, snuł opowieść o podróży po Europie Zachodniej w towarzystwie Adama Mickiewicza. Wielkim powodzeniem cieszyły się też pamiętniki Pauliny Wilkońskiej zatytułowane Moje wspomnienia o życiu towarzyskim $w$ Warszawie wydane po raz pierwszy w Poznaniu w 1871 r. ${ }^{59}$ Wilkońska, mierna literatka, a bystra obserwatorka, uczestniczka salonów literackich wykazała się znakomitą pamięcią i w żywej anegdotycznej formie dała interesujący obraz życia towarzyskiego i cyganerii artystycznej lat 40 . Tego samego okresu dotyczyły również relacje Aleksandra Niewiarowskiego (Cyganeria warszawska, 1881-1882), a Kawa literacka (1873) Kazimierza Wójcickiego przesuwała okres wspomnień do początku wieku. W latach 80. i 90.

58 D. Chłapowski, Pamiętnik, t. 1-2, Poznań 1899.

59 P. Wilkońska, Moje wspomnienia o życiu towarzyskim, Warszawa 1954. 
również Poznań uzyskał ciekawą relację kronikarską w propozycji Marcelego Mottego Przechadzki po mieście (1888-1892).

Najgłośniejszą książką wydaną za życia większości opisanych w niej pozytywistów stało się Towarzystwo warszawskie. Listy do przyjaciółki przez baronowa $X Y Z^{60}$, wydane po raz pierwszy w 1887 r. (Kraków) po oszałamiającym sukcesie pierwodruku odcinkowego w krakowskim "Czasie” (od października 1885 do stycznia 1887). Tajemniczą „baronową" miał być Antoni Zaleski, redaktor warszawskiego "Słowa”, znany z ciętego języka i literackich koneksji. Inna współczesna hipoteza (Dobrosławy Świerczyńskiej) mówi, iż książkę napisali wspólnie Julia Górska, Konstanty Górski i Stanisław Koźmian, nie podważa to jednak ważności tego świadectwa. W wielu późniejszych przekazach, choćby u Ignacego Balińskiego (Wspomnienia o Warszawie, Londyn 1946), Jadwigi Waydel-Dmochowskiej (Jeszcze o dawnej Warszawie, Warszawa 1959) czy Adama Grzymały-Siedleckiego (Niepospolici ludzie w dniu swoim powszednim, 1961) znajdujemy wiele informacji na temat popularności tego tekstu, służącego jako miarodajne źródło informacji o stosunkach polityczno-społecznych i towarzysko-obyczajowych Warszawy lat 80. Zaleski (lub owa spółka autorska) nie tylko sportretował sfery rządzące (generał-gubernatora Hurkę i jego żonę, wojskowych, sędziów, słynnego kuratora Apuchtina) i dyplomację, ale dał też przekonujący (bo nieupiększony) obraz warszawskiego środowiska dziennikarsko-literackiego. Inne portrety tego rodzaju wystawili swoim dawnym redakcjom i współpracownikom Aleksander Kraushar, autor kilku tomów wspomnieniowych, z których najwcześniej wydano Sylwetki literackie z niedawnej przeszłości (1894; później także: Neocyganeria warszawska, 1915; Czasy szkolne za Apuchtina, 1915 oraz bardziej osobiste: Kartki z pamiętnika Alkara, t. 1-2, Warszawa 1910-1913), oraz Walery Przyborowski w legendarnym, ogłoszonym pod pseudonimem Eksdziennikarz tekście Stara i nowa prasa (Petersburg 1897, ed. współ. 1998), opisującym środowisko „Przeglądu Tygodniowego" i stosunki w stołecznym dziennikarstwie.

Na przełomie wieków i na początku XX w. prócz wspomnień o charakterze obyczajowo-towarzyskim ${ }^{61}$ drukuje się także pamiętniki, których problematyka przesuwa się w stronę polityki i które wyraźnie korzystają z przywileju zelżenia cenzury. Zygmunt Kaczkowski w Pamiętniku (Lwów 1899) wraca do czasów swojej młodości, a Tomasz Teodor Jeż publikuje Sylwetki emigracyjne z doby minionej (Lwów 1904). Najwszechstronniejszym obrazem jego

60 Edycja współczesna w oprac. R. Kołodziejczyka, Warszawa 1971.

61 Zob. np. bardzo ciekawe ukraińskie Pamiętniki Tadeusza Bobrowskiego, Lwów 1900. 
życia i minionej epoki stanie się jednak obejmujący lata 1884-1909 pamiętnik Od kolebki przez życie, opublikowany w 1936 r. w Krakowie.

Do okresu konspiracji przedpowstaniowej i powstania sięgają wcześniej napisane teksty Jakuba Gieysztora, jak choćby Pamiętniki z lat 1857-1865 wydane w 1913 r. w Wilnie, Józefa Kajetana Jankowskiego Pamiętniki o powstaniu styczniowym (Kraków 1923-1931) i Ludwika Mierosławskiego Pamiętnik (Warszawa 1924). Czasy młodości wskrzesza we wspomnieniach Tadeusz Korzon - Mój pamiętnik przedhistoryczny (Kraków 1912). Ciekawy ze względu na walory etnograficzno-geograficzno-kulturowe jest pamiętnik Benedykta Dybowskiego (Lwów 1930), który na zesłaniu (1861-1878) rozwinął swoje pasje naukowe. Pokolenie Szkoły Głównej i warszawskie środowiska inteligencji zawodowej sportretowano we wspomnieniach Jana Stanisława Czarnowskiego (Pamiętniki. Wspomnienia z trzech stuleci, Warszawa 1921) oraz Anny Leo (Wczoraj. Gawęda o niedawnej przeszłości, Warszawa 1929), natomiast środowisko arystokratyczno-ziemiańskie Galicji otrzymało skandalizujący konterfekt w znakomitym utworze Ludwika Jabłonowskiego o tytule w oryginale przypominającym dzieła polskiego baroku: Czego dusza zapragnie. Nocne dumki starego Lacha. Bigos hultajski odgrzany jak przynależy ${ }^{62}$. Środowisko polskich socjalistów reprezentował syberyjskim pamiętnikiem (Ciupasem na Syberię, Warszawa 1926) Wacław Sieroszewski. Więcej XIX-wiecznych pamiętników ukaże się dopiero w latach 50. i 60. XX w.

Dla historii politycznej XIX w. ważne były ówczesne edycje: Wspomnień Ludwika Krzywickiego z lat 1859-193963, Pamiętnika 1870-1914 Stanisława Stempowskiego ${ }^{64}$ oraz Bolesława Limanowskiego ${ }^{65}$, obejmującego lata 1835-1928. Z zainteresowaniem spotkały się również teksty wydawane w pamiętnikarskiej serii Wydawnictwa Literackiego: Pamiętnik Kazimierza Chłędowskiego (t. I-II, 1957), Sprzed pót wieku Alfreda Wysockiego (1958), Władysława Zawadzkiego Pamiętniki życia literackiego w Galicji (1960), Paleta i pióro Pii Górskiej (1960), tłumaczone z angielskiego Wspomnienia i wrażenia Heleny Modrzejewskiej (1957). Artystyczne i dziennikarskie środowiska uwieczniło też pióro Ferdynanda Hoesicka ${ }^{66}$, popularnego w XIX w. dostarczyciela sensacji z życia znanych i podziwianych, oraz Kazimierza Pollaka Ze wspomnień starego dziennikarza warszawskiego (1961). Niezmiernie ciekawym

\footnotetext{
62 Opublikowane we Lwowie w 1920 r. pt. Złote czasy.

63 L. Krzywicki, Wspomnienia, t. I-III, Warszawa 1959.

64 S. Stempowski, Pamiętnik 1870-1914, Wrocław 1953.

65 B. Limanowski, Pamiętniki, t. I-IV, Warszawa 1957-1973.

66 F. Hoesick, Powieść mojego życia. Pamiętnik, t. I-II, Wrocław-Kraków 1959.
} 
świadectwem są również pamiętniki Władysława Matlakowskiego ${ }^{67}$, lekarza, zapomnianego szekspirysty, człowieka, który dzięki pracom na temat sztuki ludowej na Podhalu niezmiernie zasłużył się dla rozwoju stylu zakopiańskiego. Matlakowski - geniusz pracowitości, człowiek niepospolity w każdym calu, posiadał duży talent literacki, jego wspomnienia z lat 1850-1895 to nie tylko zapis jego niezwykłego twórczego życia, ale także świadectwo wielu pasji i podróży. Ciekawe są zarówno wspomnienia z Europy, którą na statku "Żemantyj" ogląda w latach 1875-1876, jak i zapis pobytu na Ukrainie czy w Zakopanem. Był przy tym pilnym obserwatorem życia literackiego w Warszawie.

W tych zestawieniach dotkliwie brak najważniejszych uczestników epoki postyczniowej. Szkic do pamiętnika opublikował w 1936 r. („Nasza Przyszłość”) jeden z najgłośniejszych historyków krakowskich Michał Bobrzyński, a w latach 1931-1932 ukazały się na łamach „Wiadomości Literackich” fragmenty pamiętnika Aleksandra Świętochowskiego. W postaci uzupełnionej o kilka wcześniej drukowanych artykułów i felietonów wspomnieniowych ukazały się ponownie dopiero $\mathrm{w}$ latach $60 .{ }^{68} \mathrm{I}$ to właściwie wszystko. Czy oznacza to, że nikt $\mathrm{z}$ pisarzy pozytywistycznych nie próbował pisać dziennika lub pamiętnika? Kraszewski, mimo niechęci do pamiętnikomanii kilkakrotnie przymierzał się do spisania wspomnień, nie uzyskały one jednak postaci kompletnej, scalonej intencją autora. Wydany w opracowaniu Wincentego Danka tom pamiętników autora Starej baśni to właściwie zbiór jego utworów pamiętnikarskich z różnych okresów życia, z lat szkolnych i uniwersyteckich, młodzieńczych (1832-1838), dojrzałych (lata 50.) i starości $(1879,1884-1887)^{69}$. $\mathrm{O}$ wiele bardziej konsekwentny był Kraszewski w materiałach o charakterze podróżniczo-krajoznawczym, mających wybitne walory wspomnieniowe, bardzo poczytnych w epoce Obrazach życia i podróży (1842) czy Wspomnieniach Polesia, Wotynia $i$ Litwy (1840). Henryk Sienkiewicz, jak wiadomo z jego listów do Jadwigi Janczewskiej, przez jakiś przynajmniej czas prowadził dziennik. Że formę tę uważał za niezwykle poręczną, widać w jego twórczości literackiej (od nowel przez Trylogię do Bez dogmatu), niestety dziennik pisarza spłonął podobno w powstaniu warszawskim. Autobiograficzną lukę uzupełniają w jego wypadku wspaniałe zbiory korespondencji. O pamiętniku czy dzienniku Bolesława Prusa nie wiemy nic, w „Kronice Tygodnio-

67 W. Matlakowski, Wspomnienia z życia przeszłego i teraźniejszego (1850-1895), przygot., przedmowa i komentarz J. Kapuścik, Wrocław 1991.

68 A. Świętochowski, Wspomnienia, oprac. S. Sandler, Wrocław 1966.

69 J.I. Kraszewski, Pamiętniki, wstęp, oprac. W. Danek, Wrocław 1972. 
wej" utrwalił obraz Warszawy swoich czasów, ale siebie ukrył, choć jeden z jego najbardziej tajemniczych bohaterów literackich, Ignacy Rzecki, prowadzi dziennik.

W 1957 r. Edmund Jankowski odnalazł w Wilnie przedziwny diariusz Elizy Orzeszkowej, udostępniony przed laty w opracowaniu Iwony Wiśniewskiej $^{70}$. Są to dokładnie datowane zapiski pisarki dotyczące pracy twórczej i przeżyć dnia codziennego. Nie byłoby może nic w nich dziwnego, gdyby nie to, że operują pewnym szyfrem, a ich systematyczność jest co najmniej zastanawiająca. Nie ma w nich ekstazy, minoderii czy pustosłowia, odsłania się natomiast przedziwna walka $\mathrm{z}$ samą sobą, namiętnością, której nie można ulec, bezradnością twórcy, wreszcie samotnością. Inny to dziennik niż większość zapisków skoncentrowanych na sobie artystów. W porównaniu ze wspomnieniami Stanisława Przybyszewskiego pt. Moi wspótcześni ${ }^{71}$, w których dawny geniusz i szatan stara się wybielić siebie i zamienia się w prowincjonalnego demona i gorszyciela emerytek, Orzeszkowa przekonuje szczerością i autentyzmem. Nie rozczarowuje natomiast Pamiętnik Stanisława Brzozowskiego, wydany we Lwowie w 1913 r., dopełniony listami autora i objaśnieniami Ostapa Ortwina. Brzozowski pragnął stworzyć autobiografię intelektualną (miała być częścią wydanych w 1910 r. Idei), postępująca choroba jednak zamiar ten udaremniła. Niewielki rozmiarowo Pamiętnik stał się formą zastępczą, stąd jego niesystematyczny, niezaprogramowany charakter: trochę to notatnik lektur, trochę zapiśnik refleksji spontanicznie cisnących się pod pióro, trochę polemicznych uwag, które komentują rwący potok rzeczywistości. Dla studiów nad Brzozowskim - rzecz absolutnie niezbędna, wprowadzająca dodatkowe aspekty widzenia jego twórczości, pozwalająca uchwycić ewolucję jego poglądów.

Kto nie widział notatników Reymonta przechowywanych w zbiorach Biblioteki Zakładu Narodowego im. Ossolińskich we Wrocławiu (rękopis 6954/I), ten nie wie, ile pracy trzeba było włożyć, by z nieuporządkowanych, chaotycznych zapisków stworzyć tom zatytułowany Dziennik nieciqagły 1887-192472. Nie przypominają one klasycznych zapisów dziennikowych czy pamiętnikowych, cechują się całkowitym amorfizmem, brakiem reguł. To najczęściej opisy, proste opowieści, wiersze, rachunki, projekty literackie

70 E. Orzeszkowa, Dnie, oprac. I. Wiśniewska, Warszawa 2002.

71 Druk fragmentów „Tygodnik Ilustrowany” 1924; potem także: Wśród obcych, Warszawa 1926; Wśród swoich, „Świat” 1928; wydanie współczesne: S. Przybyszewski, Moi współcześni, wstęp R. Wilhelmi, Warszawa 1959.

72 W.St. Reymont, Dziennik nieciagły, oprac. B. Utkowska, Kraków 2009. 
o charakterze elementarnym, wyrwane z kontekstu zdania. Mimo to dają wgląd w rozwój pisarza i dostrzec to można w układzie form autobiograficznych w jego twórczości: dziennik pisał w młodości, gdy nie za wiele miał do powiedzenia, prócz introspekcji; gdy rozpoczął pracę pisarską (od Pielgrzymki do Jasnej Góry, 1894), pisanie zarzucił, pochłaniała go twórczość i bycie w środowisku, na starość (od 1901) powraca projekt autobiografii. Reymont uprawia dwie formy narracji autobiograficznej: świadectwo i wyznanie, konfrontacja obu z różnych okresów jego życia czyni z nich ciekawy dokument psychologiczno-obyczajowy.

Największym dokonaniem memuarystyki przełomu XIX i XX w. pozostają jednak Dzienniki Stefana Żeromskiego, które ukazały się po raz pierwszy w latach 50. XX w. Było to 3-tomowe wydanie, pod kierownictwem Wacława Borowego, a następnie Stanisława Adamczewskiego, z przedmową Andrzeja Wasilewskiego i przypisami J. Kądzieli. Okrojone ze względów obyczajowych funkcjonowało aż do lat 70., kiedy ukazało się pierwsze 7-tomowe wydanie krytyczne w opracowaniu Jerzego Kądzieli, częściowo owe opuszczenia respektujące. W 2000 r. ukazał się Dziennik z wiosny 1891 w opracowaniu Zdzisława J. Adamczyka i Zbigniewa Golińskiego. Zespół ten planował w przyszłości pełną edycję dzieł pisarza. Historia wydań dzienników Żeromskiego pokazuje zmianę, jak dokonała się w polskiej krytyce w rozumieniu roli dziennika pisarza. Jest to również znaczące $\mathrm{w}$ odniesieniu do samego autora, tym razem nie pisarza, ale po prostu Stefana Żeromskiego, piszącego dla siebie i do siebie. Paweł Rodak, autor najnowszej monografii na temat dzienników pisarzy w XX w., pisze: „Choć w sensie kalendarzowym dziennik Żeromskiego był prowadzony jeszcze w wieku XIX (dopiero późniejsze notesy pochodzą już z wieku XX), zawiera on w zalążku wszystkie najważniejsze etapy tej historii. Pierwszy z nich można nazwać stawaniem się pisarzem w dzienniku i poprzez dziennik, drugi - wykorzystaniem praktyki diarystycznej $\mathrm{w}$ tworzeniu literatury, trzeci - nadawaniem samemu dziennikowi znaczenia literackiego. Dwa pierwsze z tych procesów łączą się z osobą samego diarysty-pisarza, trzeci również z pracami archiwistów, wydawców, krytyków, badaczy i zwykłych czytelników dziennika.

Dziennik Stefana Żeromskiego nie przypadkiem zatem rozpoczyna [...] historię dziennika polskiego pisarza w XX wieku [...], wskazuje bowiem drogę, jaką przejdą przez następne z górą 100 lat kolejne dzienniki: od Żeromskiego właśnie, poprzez Nałkowską i Dąbrowską, do Gombrowicza i Herlinga-Grudzińskiego. Najkrócej można tę historię przedstawić jako ciąg diarystycznych wcieleń: od codziennej praktyki piśmiennej, poprzez materiał 
do twórczości, następnie materiał archiwalny - aż do literatury" ${ }^{\prime 7}$. Historia pamiętnika w Polsce, w której wszystko zaczyna się od pamiątki, a kończy na odkryciu, iż dziennik lub pamiętnik może być grą z czytelnikiem, pokazuje też znamienną ewolucję postawy autobiograficznej w naszych czasach: od świadectwa do wyznania, od wyznania do wyzwania ${ }^{74}$.

\section{Abstract \\ The memoir writing. \\ The history of a term and genre in the 19th century}

The author of the article presents in a concise way the history and geology of memoir writing as a documentary writing set between literature, publicity and science. The term of memoir writing, in modern meaning 'personal document', has been rooted social consciousness relatively late - in the 40s of the 19th century and in the $50 \mathrm{~s}$, is commonly used in textbooks. The 17th and 18th century were the best periods for memoir writing but the 19th century was the period of publishing and deepening the reflection on the history of such records. This period is typical of the most remarkable attempts of theoretical presentation of the genre. The author tries to identify the phenomenon of the 19th century editorial boom, discusses the most important publishing centers and private initiatives. She also shows the most important published old memoir writing published at that time and ponders over their impact on the 19th century literature, mostly over historical novel. The reflection concerning the change in the attitude of literary criticism to diary, which took place in the 20th century, appears in the last part of the paper. From the memoir writing, which was one of many, not necessarily the most important sources of knowledge about the author and his times, to the memoir writing, which is equivalent to other works of the author having an additional value of authenticity.

Key words: memoir writing, literary genealogy, philosophy of history, editing, personal document

73 P. Rodak, Między zapisem a literaturą. Dziennik polskiego pisarza w XX wieku, Warszawa 2011, s. 137.

74 Nawiązuję tu do klasycznej już pracy M. Czermińskiej, Autobiograficzny trójkąt. Świadectwo, wyznanie i wyzwanie, Kraków 2000. 
Резюме

\section{$\Delta$ невники памяти (мемуары). Из истории термина и жанра в XIX веке}

В статье коротко представлена история термина и генеалогия документальных дневников памяти, которые находятся между литературой, публицистикой и наукой. Термин дневник в современном значении - «личный документ» - усиливается в общественном сознании, относительно поздно, в 40-х годах XIX века, чтобы в 50-х годах широко функционировать в учебниках. Поскольку XVII-XVIII века, это период расцвета писания дневников, так XIX век является эпохой их издания и углубления размышлений на тему истории, проявляясь именно в такого рода записях. Из этого периода происходят самые известные попытки теоретизации жанра. Автор пробует определить феномен XIX-вечного издательского бума, рассматривает наиболее важные издательские центры и частные инициативы, указывает на самые давние и на современные дневники, а также задумывается над их влиянием на литературу XIX века, особенно исторические повести. В завершении статьи, появляются размышления об изменении литературной критики по отношению к мемуарам, которые состоялись в XX веке. От дневника, который был одним из многих важных источников знания об авторе и его времени, который является чем-то равносильным (әквивалентным) по отношению к другим трудам автора, имеющим дополнительную ценность аутентичности.

Ключевые слова: дневник, литературная генеалогия, фрилософия истории, редактирование, личный документ 